\title{
Konut Bahçelerinin Bitkisel Tasarımında İçilebilir Türlerin Kullanımı Üzerine Kullanıcı Görüşleri: İzmir İli Örneği
}

\author{
Handan ÇAKAR (D) ${ }^{*}$, Hülya AKAT (iD) 2 , Özlem AKAT SARAÇOĞLU(iD) \\ ${ }^{1}$ Ege Üniversitesi, Bayındır Meslek Yüksekokulu, İzmir \\ ${ }^{2}$ Muğla Sıtkı Koçman Üniversitesi, Ortaca Meslek Yüksekokulu, Muğla \\ Geliş Tarihi (Received): 03.11.2020, Kabul Tarihi (Accepted): 09.12.2020 \\ $\square$ Sorumlu Yazar (Corresponding author*): handan.cakar@ege.edu.tr \\ (C) +902325817175 吾 +902325817330
}

\section{öz}

Araştırmanın amacı; konut bahçelerinde bitkisel çay olarak değerlendirilebilen türlerin kullanımı ile içilebilir peyzaj tasarımına yönelik yeni bir peyzaj yaklaşımı oluşturmak için kullanıcıların görüşlerini tespit etmek ve içilebilir peyzaj tasarımı ile ilgili öneriler geliştirmektir. Bu doğrultuda İzmir ilinin 11 ilçesindeki konut bahçesine sahip 182 kullanıcı üzerinde anket çalışması gerçekleştirilmiştir. Araştırmada konut sakinleri, içilebilir bitki türlerinin konut bahçesinde kullanımını olumlu karşılayarak içilebilir peyzaj tasarımlarının gerçekleştirilmesi sonucu bahçelerde geçirecekleri sürenin artacağını ve markalı ürünler ile kıyaslandığında bu ürünleri rahatlıkla bahçelerinden tüketebileceklerini ifade etmişlerdir. Elde edilen tüm bulgulara göre; içilebilir peyzaj tasarımı yaklaşımının, yenilebilir peyzaj anlayışına yeni bir alternatif oluşturacağı sonucuna ulaşımıştır.

Anahtar Kelimeler: İçilebilir bitkiler, içilebilir peyzaj, konut bahçeleri, tıbbi ve aromatik bitkiler, yenilebilir peyzaj

\section{Users' Opinions on the Use of Drinkable Plants in the Plant Design of Residential Gardens: A Case of Izmir Province, Turkey}

\section{ABSTRACT}

The purpose of the research is to determine the opinions of the users and to develop suggestions about drinkable landscape design in order to create a new landscape approach for drinkable landscape design with the use of plants that can be evaluated as herbal tea in residential gardens. In this direction, a survey study was carried out on 182 users with a residential garden in 11 districts of Izmir Province. In the study, residents stated that the time they spend in the gardens will increase, by accepting the use of drinkable plant species in the residential garden, as a result of the accomplishment of drinkable landscape designs and they can easily consume these products from their gardens compared to branded products. According to all the findings obtained; it was concluded that the drinkable landscape design approach would constitute a new alternative to the edible landscape concept.

Keywords: Drinkable plants, drinkable landscape, residential gardens, medical and aromatic plants, edible landscape

\section{Giriş}

Kentsel alanlar, yeryüzünün sadece \%2'sinde yer almasına rağmen dünya nüfusunun yaklaşık yarısı bu alanlarda yaşamaktadır (Grimm ve ark., 2000; Jim ve Chen, 2010). 2018 yılında 4,2 milyara yakın olan dünyanın kentsel nüfusunun 2050'de 6,7 milyara ulaşması beklenmektedir (United Nations, 2019). Dünyada giderek artan kentsel nüfusa dair intiyaçların karşılanması amacıyla inşa edilen yapıların çevreye olan olumsuz etkilerinden biri de kent sakinlerini doğadan uzaklaştırarak yapay bir çevrede yaşamaya zorunlu kılmaktır. Bu noktada, kentte 
yaşayanlar ile doğa arasında bir bağ oluşturmada önemli unsurlardan biri olarak konut bahçeleri karşımıza çıkmaktadır.

Konut düzeyindeki yeşil alanlar, kentsel açık-yeşil alanların en küçük yapı birimleridir. Özel mülkiyetli tek veya çok katlı konutların bahçeleri bu birim içinde değerlendirilmektedir. Büyüklükleri, işlevleri ve estetik etkinlikleri, konut sahiplerinin kültür ve ekonomik durumu ile orantılı olduğu kadar kentin fiziksel ve toplumsal özellikleri de bu bahçelerde önemli bir rol oynamaktadır (Gül ve Küçük, 2001). Estetik ve işlevsel özelliklere sahip olan konut bahçeleri, konut sakinlerine kent yaşamı içerisinde huzur bulabilecekleri bir ortam sağlamaktadır. Konut bahçeleri tasarlanırken, tasarımın estetik olduğu kadar işlevsel de olması kullanıcılar açısından bu alanlarda zaman geçirme sürecini arttırarak tercih edilebilirliğini etkilemektedir. Bu doğrultuda bitkisel peyzaj tasarımlarında estetik olmasının yanı sıra işlevsel özellikleriyle de bilinen bitkilerin kullanımı tasarımların cezbedici değerini ve beraberinde etkinliğini de kuvvetlendirmektedir (Dönmez ve ark., 2016).

Tüm dünyanın doğal florasında yer alan bitkiler, insanların yaşamını sürdürmesi için gerekli olan temel besinleri sağlamakta ve tedavi edici potansiyelleri ile de sağlığını korumaktadır (Koçyiğit, 2005; Faydaoğlu ve Sürücüoğlu, 2011). Bununla birlikte geçmişten itibaren barınma, savunma, ısınma, tedavi ve kozmetik gibi değişik amaçlar ile bitkilerden faydalanılırken beslenme amacıyla yiyecek ve içecek olarak kullanımı hayatta kalma ile ilgili temel bir unsur olup yaşamsal önem taşımaktadır (Burke, 2005; Göktaş ve Gıdık, 2019). Geçmiş̧e yenilebilen ya da içilebilen bitkilerin insanlar tarafından kullanımı önceden doğadan toplama şeklindeyken, insanların yerleşik bir düzene geçmesi ile bu ürünlerin kendi bahçelerinde yetiştirilmesini gündeme getirmiştir (Dönmez ve ark., 2016). Bitkiler bu alanlarda önce gıda amaçlı yetiştirilirken, hastalıklara olan faydaları keşfedilince tedavi edici özelliklerinden yararlanmak amacıyla da yetiştirilmeleri gündeme gelmiştir (Yücel ve Evren, 2010). Ancak zamanla bu olgu kentleşmeye paralel olarak bitkilerin estetik görüntülerinden faydalanmak amacıyla da kullanımları önem kazanmaya başladığında değer kaybetmeye başlamıştır (Faydaoğlu ve Sürücüoğlu, 2011). Bu anlayış ile birlikte süreç içerisinde gelişen toplum, hızlı kentleşme ve değişen bakış açısı tarım alanlarının peyzaj tasarımlarından ayrı tutulması gerekliliğini ortaya koymuştur. Ancak günümüzde gıda olarak tüketilen bitkilerin peyzajda kullanımı çok eskiye dayanmasına rağmen kentsel alanlardaki tarım alanlarının azalması veya yok olması sonucu meyve, sebze ve süs bitkisi türlerinden besin intiyacının giderilmesinin yanı sıra fonksiyonel ve estetik görüntüler elde etmek amacıyla bu bitkilere tekrardan yer verilmesi sonucu "yenilebilir peyzaj" tasarımı kavramı gündeme gelmiştir (Olgun ve ark., 2018; Yalçınalp ve Demirci, 2018; Sevik ve ark., 2020). Son yıllarda bu tasarım yaklaşımı ile birlikte sadece yenilebilir bitkilerin değil, aynı zamanda yaprak, çiçek, sürgün, meyve, kabuk ve kök gibi değişik organlarından taze ya da kurutularak yararlanılan bitkilerin içecek olarak kullanımı amacıyla özel ya da kamusal peyzaj alanlarında estetik görüntüye sahip içilebilir bitkilere de uygulamalarda yer verilmesi dikkat çekici olmuştur. Doğal ürünlere olan talebin artışı, sağlıklı yaşam için verilen mücadele ile sakinleştirici ve antioksidan etkisinin de bulunması içecek şeklinde değerlendirilebilecek bitki türlerinin önemini arttırarak yetiştiriciliğinin popüler hale gelmesine neden olmuştur (Selvi ve ark., 2013). Bitkisel çay olarak değerlendirilebilen türlerin kullanıldığı "içilebilir peyzaj" kavramının oluşturulması ve bunun da gıda güvenliği kapsamında ağır metal içerikleri açısından bir çerçeveye oturtularak uygun alanlarda gerçekleştirilmesi (Çetin ve Cobanoğlu, 2019; Turkyilmaz ve ark., 2018; Sevik ve ark., 2019; Sevik ve ark., 2020) ile yenilebilir peyzaj tasarımına alternatif yeni bir peyzaj tasarımı anlayışının ortaya konulması mümkündür.

Sahip olduğu farklı tat ve aromalar ile bitkisel çayların, geleneksel çaya alternatif oluşturmasının dışında iyileştirici etkilerinin de bulunması tüketimlerinin artmasına neden olmuştur. Günümüzde bitkisel çayların temini doğadan toplama ya da pazarlama zincirinden belli bir ücret karşılığında temin etme şeklinde olmaktadır. Artan tüketime paralel bitkisel çay amaçlı kullanılan türlerin temini doğadan toplama yöntemi ile yapıldığında, bazı bitkilerin neslinin tükenme tehlikesi bulunduğundan (Bayram ve ark., 2010) bu türlerin korunabilmesi ve sürdürülebilmesi için peyzaj tasarım çalışmalarında yer alması gerektiği bildirilmiştir (Kevseroğlu ve ark., 2014). Bu doğrultuda da içilebilir peyzaj tasarımlarının oluşturulması ile türlerin sürdürebilirliğinin yanı sıra bitkisel çaylara daha kolay ve pratik bir şekilde ulaşılabilme imkânı da sağlanacaktır.

Kentsel alanlarda ulaşım sıkıntısı çekmeden doğayla baş başa vakit geçirebilecek ve rahatlıkla fiziksel aktivitede bulunabilecek ortamların oluşturulmasında konut bahçeleri önemli bir yere sahiptir. İçilebilir bitki türleriyle tasarlanmış konut bahçelerinin; kişilerin güvenli gıdaya ulaşabilmesi, konut sakinlerinin bu bitkilerin büyüme ve gelişme süreçlerine dâhil edilmesi sonucu yaşayan bahçe kavramının oluşturulması ile tüketimden ziyade üretimde de aktif rol alabilmeleri açısından önem taşımaktadır. Bu bağlamda konut bahçelerinin peyzaj tasarımlarındaki bitki seçimlerinde estetik değeri ve görsel kalitesi yüksek olan içilebilir bitki türlerine yer verilmesi ile konut sakinlerinin kendi intiyacı olan ürünlerin yetiştiriciliğine imkân tanınarak yenilebilir peyzaj tasarımına içilebilir bitkilerin kullanımı ile alternatif sunularak içilebilir peyzaj tasarım kavramının çerçevelendirilmesinin 
sağlanması önemli bir bakış açısı olarak ortaya çıkmaktadır.

Tasarımlarda, bir temaya ait olsa dahi bitki tercihi yapılırken bitkilerin ekolojik istekleri ve fonksiyonel kullanımları kadar sergiledikleri estetik görünüşleri de göz önünde bulundurulmaktadır. Bitkilerin yaprakları, çiçekleri, meyveleri, dalları, sürgünleri ile kabuklarının rengi, şekli ve dizilişi gibi özellikleri tasarımlarda kullanım alanlarını belirlemekte ve etkili kompozisyonların oluşturulabilmesini sağlamaktadır (Dönmez ve ark., 2016). Bu bağlamda da son zamanlarda estetik ve fonksiyonel etkileri olan tıbbi ve aromatik bitkilerin koleksiyon, şifa-terapi, botanik, kaya, çatı, teras bahçeleri ile kuru taş duvarlar, parterler, saksılar, eğimli alanlar ve yollar gibi değişik peyzaj tasarımlarında kullanımı (Arslan ve ark., 2018) giderek dikkat çekmekte ve bu gruba giren bir çok bitki türünden de bitkisel çay olarak faydalanılmaktadır (Erbaş, 2013; Dönmez ve ark., 2016; Pouya ve Demir, 2017; Kösa ve Güral, 2019).

İçilebilir peyzaj tasarımlarında kullanılabilecek bitkilerden demleme (infüzyon) ve kaynatma (dekoksiyon) yönteminden yararlanılarak daha çok sıcak içecek olarak faydalanılmakta ve ülkemizde bu kullanım tarzlarından en yaygın infüzyon yöntemi tercih edilmektedir (Kökdil,
2002; Bulut, 2005). Bununla birlikte İzmir ilinde; gıda olarak meyveleri tüketilerek yenilebilir bitkiler arasında yer alan ve peyzaj tasarımlarında konut sakinlerinin küçük çapta kendi besin ihtiyaçlarını karşılamak amacıyla kullanılabilen elma, ayva, böğürtlen, muşmula, portakal, mandarin, limon, dut ve avokado gibi meyve türleri ile melisa, pelin otu, okaliptus, mersin, defne, sığla, sinameki, limon otu gibi tıbbi ve aromatik bitki türlerinin yapraklarından bitkisel çay olarak faydalanılmakta ve bu bitkiler içilebilir peyzaj tasarımları için estetik görüntüleri nedeniyle de uygun türler arasında yer almaktadır. Ayrıca kiraz türünün meyve saplarından, kuşburnu ve hayıt türlerinin meyvelerinden, iğde ile mürverin meyve ve çiçeklerinden, ada çayı, fesleğen, funda, ıhlamur, lavanta ve kekik türlerinin yaprak ve çiçeklerinden, ahududu, karabaş otu, ölmez çiçek, mayıs papatyası, gül hatminin çiçeklerinden, katran ardıcının yaprak, meyve ve tohumlarından, biberiye türünün ise toprak üstü kısımlarından bitkisel çay olarak faydalanılmaktadır (Tablo 1) (Yücer ve Altıntaş 2012; Sıcak ve ark., 2013; Kırıcı, 2015, Karataş ve ark., 2019). Bu bahsi geçen bitkilerin sahip olduğu işlevsel özelliklerin yanı sıra sergilediği dekoratif görüntüler nedeniyle kentsel açık yeşil alanlardaki bitkisel peyzaj tasarımlarında kullanımlarına rastlanmaktadır.

Tablo1. İzmir'de bitkisel çay olarak değerlendirilebilen ve içilebilir peyzaj tasarımlarında tercih edilebilecek türlerin listesi (Aslantürk, 2010; Sarı ve ark., 2010; Erbaş, 2013; Selvi ve ark., 2013; Atilabey ve ark., 2015; Gül ve Seçkin Dinler, 2016; Kurt ve Karaoğul, 2018)

\begin{tabular}{|c|c|c|c|c|c|}
\hline Familya & Bilimsel adı & Yöresel adı & $\begin{array}{l}\text { Kullanılan } \\
\text { kısmı }\end{array}$ & $\begin{array}{l}\text { Kullanımı } \\
\text { şekli }\end{array}$ & Kullanım amacı \\
\hline \multirow{7}{*}{ Rosaceae } & Malus communis L. & Elma & Yaprak & İnüzyon & Soğuk algınlığı, hazımsızlık, yorgunluk \\
\hline & Cydonia vulgaris $\mathrm{L}$. & Ayva & Yaprak & İnfüzyon & Soğuk algınlığı \\
\hline & Rubus idaeus $\mathrm{L}$. & Ahududu & Çiçek & Dekoksiyon & Kalp hastalıkları, kolon kanseri \\
\hline & Rubus fruticosus $\mathrm{L}$. & Böğürtlen & Yaprak & İnfüzyon & İdrar söktürücü, tansiyon, şeker hastalığı \\
\hline & Rosa canina $\mathrm{L}$. & $\begin{array}{l}\text { Kuşburnu, itburnu, } \\
\text { yabani gül }\end{array}$ & Meyve & Dekoksiyon & Soğuk algınlığı, şeker hastalığı \\
\hline & Mespilus germanica L. & $\begin{array}{l}\text { Muşmula, Döngel, } \\
\text { Beşbıyık }\end{array}$ & Yaprak & İnfüzyon & $\begin{array}{l}\text { Börek taşları, idrar söktürücü, şeker hasta- } \\
\text { lığı }\end{array}$ \\
\hline & Cerasus avium L. & Kiraz & $\begin{array}{l}\text { Meyve } \\
\text { sapları }\end{array}$ & İnfüzyon & Böbrek taşı ve iltihabı, zayflama \\
\hline \multirow{3}{*}{ Rutaceae } & Citrus sinensis L. & Portakal & Yaprak & İnfüzyon & Soğuk algınlığı, bademcik iltihabı \\
\hline & Citrus reticulata $\mathrm{L}$. & Mandarin & Yaprak & İnfüzyon & \\
\hline & Citrus limon $\mathrm{L}$. & Limon & Yaprak & İnfüzyon & \\
\hline Moraceae & Morus alba L. & Dut & Yaprak & İnfüzyon & İdrar söktürücü, tansiyon, şeker hastalığı \\
\hline Lauraceae & Persea americana Mill. & Avokado & Yaprak & İnfüzyon & Böbrek taşları \\
\hline $\begin{array}{l}\text { Elaeagna- } \\
\text { ceae }\end{array}$ & Elaeagnus angustifolia L. & İğde & $\begin{array}{l}\text { Meyve ve } \\
\text { çiçek }\end{array}$ & Dekoksiyon & İshal, öksürük \\
\hline
\end{tabular}




\begin{tabular}{|c|c|c|c|c|c|}
\hline Familya & Bilimsel adı & Yöresel adı & $\begin{array}{l}\text { Kullanılan } \\
\text { kısmı }\end{array}$ & $\begin{array}{l}\text { Kullanımı } \\
\text { şekli }\end{array}$ & Kullanım amacı \\
\hline \multirow{7}{*}{$\begin{array}{l}\text { Lamiaceae } \\
\text { (Labiatae) }\end{array}$} & Salvia tomentosa $\mathrm{L}$. & Ada çayı & $\begin{array}{l}\text { Yaprak ve } \\
\text { çiçek }\end{array}$ & İnfüzyon & Soğuk algınlığı, öksürük, boğaz iltihabı \\
\hline & $\begin{array}{l}\text { Lavandula angustifolia } \\
\text { Mill. }\end{array}$ & Lavanta & Çiçek & İnfüzyon & Sakinleştirici \\
\hline & Lavandula stoechas L. & Karabaş otu & Çiçek & İnfüzyon & Soğuk algınlığı, mide rahatsızlıkları \\
\hline & Rosmarinus officinalis L. & Biberiye, Kuşdili & $\begin{array}{l}\text { Toprak } \\
\text { üstü kı- } \\
\text { sımları }\end{array}$ & İnfüzyon & $\begin{array}{l}\text { Mide rahatsızlıkları, migren, soğuk algın- } \\
\text { lığı, zayıflama }\end{array}$ \\
\hline & Thymus serpyllum L. & Kekik & $\begin{array}{l}\text { Yaprak ve } \\
\text { çiçek }\end{array}$ & İnfüzyon & $\begin{array}{l}\text { Mide rahatsızlıkları, idrar söktürücü, solu- } \\
\text { num yolları enfeksiyonu, adet ağrıları }\end{array}$ \\
\hline & Melissa officinalis L. & Melisa, Oğul otu & Yaprak & İnfüzyon & $\begin{array}{l}\text { Mide rahatsızlıkları, idrar söktürücü, diş } \\
\text { ağrısı }\end{array}$ \\
\hline & Ocimum basilicum L. & Fesleğen & $\begin{array}{l}\text { Yaprak ve } \\
\text { çiçek }\end{array}$ & İnfüzyon & Mide rahatsızlıkları, böbrek taşları \\
\hline \multirow{3}{*}{$\begin{array}{l}\text { Asteraceae } \\
\text { (Compositae) }\end{array}$} & Helichrysum arenarium L. & $\begin{array}{l}\text { Ölmez çiçek, Altın } \\
\text { otu }\end{array}$ & Çiçek & İnfüzyon & İdrar söktürücü, böbrek taşları \\
\hline & Matricaria chamomilla L. & Mayıs Papatyası & Çiçek & İnfüzyon & Sakinleştirici \\
\hline & Artemisia absinthium L. & Pelin otu & Yaprak & İnfüzyon & İdrar söktürücü \\
\hline \multirow[t]{2}{*}{ Myrtaceae } & $\begin{array}{l}\text { Eucalyptus } \\
\text { globulus L. }\end{array}$ & $\begin{array}{l}\text { Okaliptus, Sıtma } \\
\text { ağacı, Sulfata } \\
\text { ağacı }\end{array}$ & Yaprak & İnfüzyon & Sinüzit, nezle, bronşit, nefes darlığı \\
\hline & Myrtus communis L. & Mersin & Yaprak & İnfüzyon & Öksürük \\
\hline Lauraceae & Laurus nobilis $\mathrm{L}$. & Defne & Yaprak & İnfüzyon & $\begin{array}{l}\text { Mide rahatsızlıkları, migren, idrar söktü- } \\
\text { rücü }\end{array}$ \\
\hline $\begin{array}{l}\text { Cupressa- } \\
\text { ceae }\end{array}$ & Juniperus oxycedrus L. & Katran Ardıcı & $\begin{array}{l}\text { Yaprak, } \\
\text { meyve ve } \\
\text { tohum }\end{array}$ & $\begin{array}{l}\text { İnfüzyon ve } \\
\text { dekoksiyon }\end{array}$ & $\begin{array}{l}\text { İdrar söktürücü, iştah açıcı, mide rahatsız- } \\
\text { lıkları }\end{array}$ \\
\hline $\begin{array}{l}\text { Hamamelida- } \\
\text { ceae (Altingi- } \\
\text { aceae) }\end{array}$ & $\begin{array}{l}\text { Liquidambar orientalis } \\
\text { Mill. }\end{array}$ & $\begin{array}{l}\text { Sığla, Günlük } \\
\text { ağacı, Amber } \\
\text { ağacı }\end{array}$ & Yaprak & İnfüzyon & Astım, bronşit \\
\hline Adoxaceae & Sambucus nigra L. & Kara Mürver & $\begin{array}{l}\text { Çiçek ve } \\
\text { meyve }\end{array}$ & İnfüzyon & Soğuk algınlığı, öksürük, \\
\hline Ericaceae & Erica arborea L. & Funda & $\begin{array}{l}\text { Yaprak ve } \\
\text { çiçek }\end{array}$ & İnfüzyon & İdrar söktürücü \\
\hline Verbenaceae & Vitex agnus-castus L. & Hayıt & Meyve & İnfüzyon & Nezle, hemoroit, nefes darlığı \\
\hline Tiliaceae & Tilia tomentosa Moench. & Ihlamur & $\begin{array}{l}\text { Yaprak ve } \\
\text { çiçek }\end{array}$ & İnfüzyon & Soğuk algınlığı, öksürük, bronşit \\
\hline Leguminosae & Cassia grandis L. & Sinameki & Yaprak & İnfüzyon & Kabızlık, toksin atıcı, zayıflama \\
\hline Malvaceae & Althea officinalis $\mathrm{L}$. & Gül Hatmi & Çiçek & İnfüzyon & Öksürük \\
\hline Gramineae & Cymbopogon citratus & Limon Otu & Yaprak & İnfüzyon & $\begin{array}{l}\text { Ağrı kesici, ateş düşürücü, sindirimi kolay- } \\
\text { laştırıcı, iltihap giderici }\end{array}$ \\
\hline
\end{tabular}

Araştırma kapsamında; görsel etkiye sahip, bitkisel çay olarak değerlendirilebilen ve içilebilir peyzaj tasarımında kullanılabilecek türlerin, kentsel alanlarda yer alan konut bahçelerindeki öneminin vurgulanması amacıyla konut sakinlerinin bakış açıları tespit edilerek içilebilir peyzaj tasarımı ile ilgili önerilerin geliştirilmesi hedeflenmiştir.

\section{MATERYAL VE YÖNTEM}

Türkiye'nin batısında, Ege Bölgesi'nde yer alan İzmir ili; ülkenin önemli ticaret ve turizm merkezlerinden birisidir. Yüz ölçümü $11.891 \mathrm{~km}^{2}$ olan ilde, yarımada ve koylardan oluşan 629 km'lik kıyı şeridinin 101 km'sinde doğal plajlar yer almaktadır. Batıda Ege Denizi, kuzeyde Balıkesir, 
güneyde Aydın ve doğuda Manisa il sınırı ile çevrelenmiştir (URL-1, 2020; URL-2, 2020).

2020 TÜIKK verilerine göre; 2019 yılı nüfusu 4367251 olan Il'de 30 ilçe ve belediye bulunmaktadır (TÜİK,
2019). Araştırma, İl merkezinde bulunan Balçova, Bayraklı, Bornova, Buca, Çiğli, Gaziemir, Güzelbahçe, Karabağlar, Karşıyaka, Konak ve Narlıdere ilçelerinde yer alan konut bahçelerinde yürütülmüştür (Şekil 1).

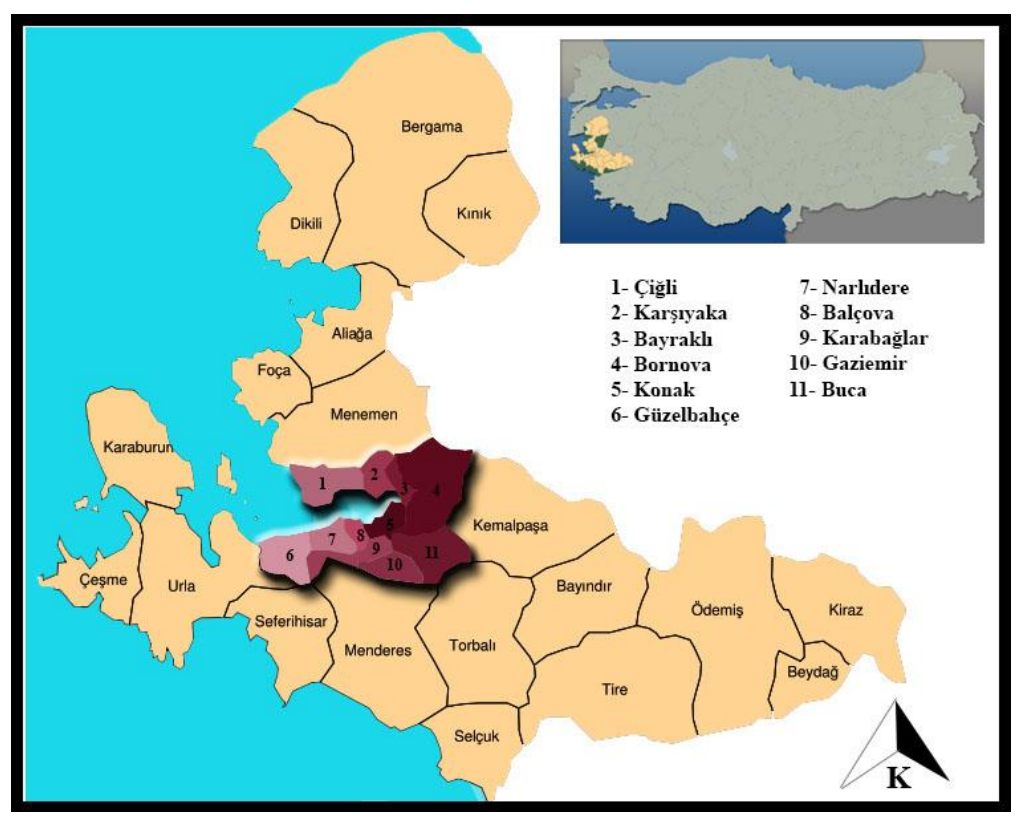

Şekil 1. Çalışma alanı (URL-3, 2020)

Çalışmada, gerek literatür taramasından elde edilen bilgiler, gerekse konut bahçelerinin mevcut durumu dikkate alınarak 3'lü Likert tipi 12 maddelik kapalı uçlu ve 8 maddelik açık uçlu olmak üzere toplam 20 adet sorudan oluşan anket formu hazırlanmıştır (Olgun ve ark., 2018). Anket formu, 2019 yılı Mayıs ayında yukarıda bahsi geçen ilçelerde yer alan bahçeli konutlarda gönüllülük esasına dayalı olarak tesadüfi bir şekilde her konuttan sadece bir kullanıcının katılımı sonucu seçilen 182 birey üzerinde uygulanmıştır.

Bu çalışmada elde edilen verilerin değerlendirilmesinde ortalama ve yüzde hesapları kullanılmıştır. Normal dağııış göstermemesi nedeniyle konut kat sayısı gruplarına göre bahçe büyüklüklerinin istatistiksel olarak farklılık gösterme durumunu ortaya koymak için Kruskal-Wallis testi kullanılmıştır. Konut bahçelerinde içilebilir bitki türlerinin kullanımına yönelik çeşitli önermelere ankete katılan bireylerin görüşleri likert ölçek ortalaması ile ortaya konulmuştur. Likert ölçek ortalamasında 1: "katılmıyorum", 2: "fikrim yok", 3: "katılıyorum" şeklinde yorumlanmaktadır. Verilerin analizinden SPSS 25 paket programı kullanılmıştır. Analiz sonucu elde edilen veriler yorumlanarak, içilebilir bitkilerin konut bahçelerinde kullanılabilirliği üzerine öneriler geliştirilmiştir.

\section{BULGULAR VE TARTIŞMA}

İzmir ilinin merkezindeki ilçelerinde yer alan konut bahçelerinde yürütülen araştırmaya katılan bireylerin demografik özellikleri Tablo 2'de gösterilmiştir. Görüşülen bireylerin \%57,1'ini kadınlar, \%42,9'unu erkekler oluşmaktadır. Yaş ortalaması yaklaşık 41 olan bireylerin \%35,2'si 34 yaş ve altı, \%64,8'i 35 yaş ve üzerindedir. Eğitim durumlarına göre bireylerin \%13,2'si ilkokul, $\% 13,2$ 'si ortaokul, $\% 26,9$ 'u lise, $\% 36,8$ 'i üniversite, $\% 9,8$ 'i lisansüstü eğitim mezunudur. Ayrıca, katılımcıların \%58,'i çalışan, \%11,5'i emekli, \%20,9'u ev hanımı, $\% 8,8$ 'i öğrenci grubunda yer almaktadır (Tablo 2).

Araştırmaya dahil edilen konutların \%20,9'unu müstakil evler, \%54,9'unu 5 ve daha az sayıda kat bulunan apartmanlar ve \% 24,1'ini 5 katın üzerindeki apartmanlar oluşturmaktadır. Konutlardaki daire sayısı da kat sayısı ile paralellik arz etmekte olup, konutların \%24,1'inde 11 ve üzerinde daire bulunmaktadır.

Konut bahçelerinin \%31,9'u $50 \mathrm{~m}^{2}$ 'den küçük olup, $\% 44,5$ 'i $50-249 \mathrm{~m}^{2}, \% 17$ 'si ise $250-499 \mathrm{~m}^{2}$ arasındadır. $500 \mathrm{~m}^{2}$ ve üzerinde bahçesi olan konutların oranı $\% 6,5$ 'tir. Konutların \% 71,5'inde tek cephede (\%29,7 ön, $\% 35,2$ arka ve \%6,6 yan), \%15,3'ünde iki cephede, 
\%13,2'sinde 3 cephede de bahçe bulunmaktadır (Tablo

$3)$.

Tablo 2. Görüşülen Bireylerin Demografik Özellikleri

\begin{tabular}{|c|c|c|c|}
\hline Özellik & Seviye & $f$ & $\%$ \\
\hline \multirow[t]{2}{*}{ Cinsiyet } & Kadın & 104 & 57.1 \\
\hline & Erkek & 78 & 42.9 \\
\hline \multirow[t]{5}{*}{ Yaş } & $\leq 34$ & 64 & 35.2 \\
\hline & $35-49$ & 69 & 37.9 \\
\hline & $50-64$ & 26 & 14.3 \\
\hline & $\geq 65$ & 23 & 12.6 \\
\hline & Ortalama yaş & 41.13 (yıl) & \\
\hline \multirow[t]{6}{*}{ Eğitim Durumu } & Ílkokul & 24 & 13.2 \\
\hline & Ortaokul & 24 & 13.2 \\
\hline & Lise & 49 & 26.9 \\
\hline & Üniversite & 67 & 36.8 \\
\hline & Yüksek Lisans & 17 & 9.3 \\
\hline & Doktora & 1 & .5 \\
\hline \multirow[t]{4}{*}{ Çalışma Durumu } & Çalışıyor & 107 & 58.8 \\
\hline & Emekli & 21 & 11.5 \\
\hline & Ev Hanımı & 38 & 20.9 \\
\hline & Öğrenci & 16 & 8.8 \\
\hline
\end{tabular}

Tablo 3. Konut ve Bahçe Özellikleri

\begin{tabular}{llcl}
\hline Özellik & Seviye & $\mathbf{f}$ & $\%$ \\
\hline Konuttaki Daire Sayısı & $\mathbf{1}$ (müstakil) & 38 & 20.9 \\
& $\mathbf{2 - 1 0}$ & 100 & 54.9 \\
& $\mathbf{1 1 - 1 8}$ & 14 & 7.7 \\
& $\mathbf{1 9 - 3 6}$ & 19 & 10.4 \\
& $\mathbf{2 3 7}$ & 11 & 6.0 \\
\hline Bahçe büyüklüğü $\left.\mathbf{( m}^{\mathbf{2}}\right)$ & $<\mathbf{5 0}$ & 58 & 31.9 \\
& $\mathbf{5 0 - 9 9}$ & 24 & 13.2 \\
& $\mathbf{1 0 0 - 2 4 9}$ & 57 & 31.3 \\
& $\mathbf{2 5 0 - 4 9 9}$ & 31 & 17.0 \\
& $\mathbf{5 0 0 - 9 9 9}$ & 3 & 1.6 \\
& $\mathbf{1 0 0 0 - 2 0 0 0}$ & 7 & 3.8 \\
& $>\mathbf{2 0 0 0}$ & 2 & 1.1 \\
\hline Bahçenin konumu & Sadece ön & 54 & 29.7 \\
& Sadece arka & 64 & 35.2 \\
& Sadece yan & 12 & 6.6 \\
& Ön-arka & 10 & 5.5 \\
& Ön-yan & 11 & 6.0 \\
& Yan-arka & 7 & 3.8 \\
& Ön-yan-arka & 24 & 13.2 \\
\hline
\end{tabular}


Bahçelerin büyüklükleri konutlardaki kat sayısına göre değişmektedir. Araştırmadaki konut bahçelerinin büyüklüğünün ortalaması $219,10 \mathrm{~m}^{2}$ olarak belirlenirken, kat sayısı 5 'in üzerinde olan konutların bahçe büyüklüğünün ortalaması 436,64 $\mathrm{m}^{2}$ ile ortalamanın üzerinde olduğu görülmüştür. Beklenildiği gibi, müstakil konutlarda da or- talama bahçe büyüklüğü yüksek bulunmuştur. İstatistiksel olarak müstakil, 5 ve daha az sayıda ile 5 'in üzerindeki sayıda kat bulunan konutların bahçe büyüklükleri arasında anlamlı bir farklılık saptanmıştır (Tablo 4).

Tablo 4. Bahçe büyüklüklerinin konutların kat sayısına göre dağılımı

\begin{tabular}{|c|c|c|c|c|c|}
\hline & Konut kat sayısı & $\mathbf{f}$ & Ortalama Bahçe Büyüklüğü & $\begin{array}{l}\text { Kruskal-Wallis Testi De- } \\
\text { ğeri }\end{array}$ & P-değeri \\
\hline \multirow{4}{*}{$\begin{array}{l}\text { Bahçe büyüklüğü } \\
\left(m^{2}\right)\end{array}$} & Müstakil & 38 & 173.97 & \multirow{4}{*}{26.163} & \multirow{4}{*}{$.000^{*}$} \\
\hline & 5 ve daha az & 100 & 140.53 & & \\
\hline & 5'in üzeri & 44 & 436.64 & & \\
\hline & Toplam & 182 & 219.10 & & \\
\hline
\end{tabular}

Daire başına konut bahçesi büyüklüğü genel ortalama 22,25 $\mathrm{m}^{2}$ olarak belirlenirken, Gaziemir İlçesi'nin daire başına konut bahçesi büyüklüğü açısından ortalamasının $97,05 \mathrm{~m}^{2}$ değeri ile ortalamanın çok üzerinde ve Narlıdere İlçesi'nin ise $8,18 \mathrm{~m}^{2}$ değeri ile ortalamanın altında kalarak daire başına konut bahçesi büyüklüğü açısından en düşük değeri ortaya koyduğu saptanmıştır (Tablo 5).

Tablo 5. Daire başına konut bahçesi büyüklüğü dağııımı

\begin{tabular}{llcccc}
\hline Sayı & Ilıçeler & Konut sayısı & Daire sayısı & Bahçe büyüklüğü $\left(\mathbf{m}^{2}\right)$ & Ortalama \\
\hline $\mathbf{1}$ & Balçova & 5 & 14 & 425 & 30.36 \\
$\mathbf{2}$ & Bayrakı & 9 & 49 & 982 & 20.04 \\
$\mathbf{3}$ & Bornova & 40 & 598 & 12.994 & 21.73 \\
$\mathbf{4}$ & Buca & 41 & 549 & 8.855 & 16.13 \\
$\mathbf{5}$ & Çiğli & 9 & 142 & 1.840 & 12.96 \\
$\mathbf{6}$ & Gaziemir & 10 & 61 & 5.920 & 97.05 \\
$\mathbf{7}$ & Güzelbahçe & 10 & 20 & 1.429 & 71.45 \\
$\mathbf{8}$ & Karabağlar & 20 & 114 & 1.657 & 14.54 \\
$\mathbf{9}$ & Karşıyaka & 21 & 115 & 3.594 & 31.25 \\
$\mathbf{1 0}$ & Konak & 13 & 53 & 1.550 & 29.25 \\
$\mathbf{1 1}$ & Narlıdere & 4 & 77 & 630 & 8.18 \\
\hline & TOPLAM & $\mathbf{1 8 2}$ & $\mathbf{1 7 9 2}$ & $\mathbf{3 9 . 8 7 6}$ & $\mathbf{2 2 . 2 5}$ \\
\hline
\end{tabular}

Tablo 6'da ise konut bahçelerinde içilebilir bitki türlerinin kullanımına yönelik çeşitli önermelere ankete katılan bireylerin görüşleri sunulmuştur. Bireylerin görüşleri likert ölçek ortalaması ile ortaya konulmuştur. Anket sonuçları kullanıcıların konut bahçelerinde içilebilir bitki türlerine yer verilmesi yönünde olumlu görüşte olduğunu göstermektedir.

Bireylerin en çok katıldığı, "konut bahçelerinde içilebilir bitki türlerinin bulunması insan sağlığı açısından tehlike oluşturmamaktadır", "konut bahçelerindeki içilebilir bitkilerden içerim", "konut bahçelerindeki içilebilir bitkileri çocuğuma içiririm" ve "konut bahçelerinde içilebilir bitki türlerinin bulunması çocuklar için tehlike oluşturmamaktadır" önermeleri için kullanıcıların olumlu görüşleri, içilebilir bitkilerin konut bahçesinde sağlık açısından yadırganmadığının bir kanıtı olarak değerlendirilebilir.

Bireylerin çok katıldığı "İçilebilir bitkileri görsem tanırım”, "Markalı bitki çaylarından almaktansa, çayımı konut bahçesindeki içilebilir bitkilerden elde etmeyi tercih ederim" 
ve "Konut bahçelerinde bulunan içilebilir bitki türlerinden daha önce içtim" önermeleri için kullanıcıların içilebilir özellikteki bitkileri rahatlıkla tanımanın yanı sıra ücretsiz ve güvenli bir şekilde kendi bahçelerinden temin ederek içmeyi tercih ettiklerini belirttiği yönündeki görüşler, içilebilir bitkilerin tasarımda değerlendirilmeleri açısından diğer önemli bir kriterdir.

"Konut bahçelerindeki içilebilir bitkiler estetik olarak güzel bir görüntü sunmaktadır", "İçilebilir bitki türlerinden elde edilecek ürünlerin paylaşımı komşular arasında sorun oluşturmamaktadır", "Bir konut bahçesinde içilebilir bitki bulunması, bahçede vakit geçirmek için bir tercih sebebidir" ve "İçilebilir bitki türlerinin konut sakinlerinin rahatça ulaşabileceği konut bahçelerinde bulunması, zararlı içeceklerin tercih edilme oranını düşürmektedir" önermelerine sunulan görüşler ise çok olmasa da bireylerin katıldığı önermeler arasında yer almaktadır.

Bireylerin az katıldığı önerme ise "konut bahçelerinde diğer peyzaj bitkilerindense, içilebilir bitki türlerinin kullanımını tercih ederim" olmuştur. Bu da estetik açıdan içilebilir bitki türlerinin, tasarım bitkilerine oranla daha az çekici olmasından kaynaklı olarak iki bitki türü grubunu birlikte görmek istemesi şeklinde yorumlanabilir.

Tablo 6. Konut bahçelerinde içilebilir bitki türlerinin kullanımına yönelik önermeler ve kullanıcı görüşleri

\begin{tabular}{|c|c|c|}
\hline Önermeler & $\bar{x}$ & $\begin{array}{r}\text { Std. } \\
\text { Sapma }\end{array}$ \\
\hline İçilebilir bitkileri görsem tanırım & 2.79 & .504 \\
\hline Konut bahçelerindeki içilebilir bitkiler estetik olarak güzel bir görüntü sunmaktadır & 2.66 & .659 \\
\hline Konut bahçelerinde diğer peyzaj bitkilerindense, içilebilir bitki türlerinin kullanımını tercih ederim & 2.49 & .756 \\
\hline Konut bahçelerinde bulunan içilebilir bitki türlerinden daha önce içtim & 2.73 & .682 \\
\hline Konut bahçelerindeki içilebilir bitkilerden içerim & 2.87 & .434 \\
\hline Konut bahçelerindeki içilebilir bitkileri çocuğuma içiririm & 2.81 & .506 \\
\hline Konut bahçelerinde içilebilir bitki türlerinin bulunması insan sağlığı açısından tehlike oluşturmamaktadır & 2.88 & .374 \\
\hline Konut bahçelerinde içilebilir bitki türlerinin bulunması çocuklar için tehlike oluşturmamaktadır & 2.81 & .456 \\
\hline Bir konut bahçesinde içilebilir bitki bulunması, bahçede vakit geçirmek için bir tercih sebebidir & 2.62 & .701 \\
\hline İçilebilir bitki türlerinden elde edilecek ürünlerin paylaşımı komşular arasında sorun oluşturmamaktadır & 2.63 & .667 \\
\hline Markalı bitki çaylarından almaktansa, çayımı konut bahçesindeki içilebilir bitkilerden elde etmeyi tercih ederim & 2.76 & .599 \\
\hline $\begin{array}{l}\text { İçilebilir bitki türlerinin konut sakinlerinin rahatça ulaşabileceği konut bahçelerinde bulunması, zararlı içeceklerin } \\
\text { tercih edilme oranını düşürmektedir }\end{array}$ & 2.57 & .761 \\
\hline
\end{tabular}

$\overline{\bar{x}}$ : likert ölçek ortalaması; katılmıyorum:1 fikrim yok:2 katılıyorum:3

\section{SONUÇ VE ÖNERILER}

Ülkemiz, zengin bitki çeşitliliği sayesinde içilebilir bitkiler için önemli bir potansiyele sahiptir. Doğal olarak ülkemizde bulunan içilebilir bitkiler, bitkisel çay olarak faydalanılmalarının yanı sıra sahip oldukları renk, form ve doku özellikleri gibi dekoratif görüntüleri nedeniyle bitkisel tasarım çalışmalarında süs bitkisi olarak da kullanılmalarını gündeme getirmektedir. Bu açıdan, bitkisel peyzaj tasarımlarında ithal edilen egzotik bitkilerdense içilebilir bitkilerin kullanımına yer verilmesi bitki çeşitliliğini sağlamanın yanında hem doğal olmalarıyla sürdürülebilirlik açısından avantaj sağlarken hem de ekonomik anlamdaki katkılarından dolayı tercih edilmelerini giderek arttırmaktadır. Özellikle konut bahçelerinde ortam koşullarına kolaylıkla uyum sağlayan doğal bitki türlerinin kullanımı, ekolojik isteklerinin karşılanması amacıyla yapılan bakım işlemleri açısından yüksek maliyet gerektirmemesi ve sürdürülebilirliğin sağlanması açısından önemli bir faktördür.
Araştırma kapsamında kentsel alanlardaki konut bahçelerinde içilebilir bitki türlerinin kullanımı konut sakinleri tarafından olumlu karşılanarak içilebilir peyzaj tasarımlarının gerçekleştirilmesi ile bahçede geçirecekleri sürenin artacağı yönünde fikir belirtmişlerdir. Ayrıca pazarlama zincirindeki markalı bitkisel çaylar ile kıyaslandığında bu ürünleri rahatıkla bahçelerinden tüketebileceklerini ifade etmişlerdir. İçilebilir bitkilerin konut bahçelerinden temini konusunda hem kendileri hem de çocuklarının sağlığı açsından bir risk oluşturmayacağı yönündeki çok sayıdaki katıımcının olumlu görüşü ise uygulama yetersizliği ve bu konuda gıda güvenliği denetiminin yapılmamasından dolayı araştırılmaya açık bir konu olarak karşımıza çıkmaktadır.

İçilebilir peyzaj tasarımı kavramının kullanıcı görüşlerinin dikkate alınarak çerçevelendirilmesi ile içilebilir bitkilerin konut bahçelerinde değerlendirilmesinde konut sakinleri tarafından sağlık açısından bilinçsiz tüketimleri konusunda da dikkat edilmesi gerekmektedir. Yine kent 
merkezlerindeki yoğun trafiğin olmadığı konut bahçelerindeki bitkisel peyzaj tasarımlarında içilebilir bitkilere yer verilmesi, insan sağlığını olumsuz etkileyen ağır metal toksitesi açısından da avantaj oluşturacaktır. Ayrıca, içilebilir bitkiler ile oluşturulacak peyzaj tasarımlarının gerçekleştirilmesinden sonraki süreçte mutlaka bitkisel çay olarak kullanılan bu bitkilerin ağır metal analizleri yapılarak insan sağlığı açısından değerlendirmelerinin yapılması gerekmektedir.

Bitkisel çayların elde edildiği türlerin doğadan yanlış ve aşırı biçimde toplanması biyoçeşitliliği azaltmakta ve özellikle süreç içinde endemik türlerin yok olması ile karşı karşıya kalınabilme durumu söz konusu olmaktadır. Bu doğrultuda, yeni bir kullanım sahası olarak bu bitkilerin içilebilir peyzaj tasarımlarında değerlendirilmesi türlerin korunması ve sürdürülebilirliğine de katkı sağlayacaktır. Ayrıca, içilebilir bitkilerin doğadan toplanması yerine süs bitkisi yetiştiriciliği yapan firmalar tarafından üretimlerinin teşvik edilmesi sürdürülebilirlik açısından önem taşımaktadır.

Bitkisel peyzaj tasarımında içilebilir bitkilerin kullanılması ile estetik, sağlık ve ekonomik fayda sağlanmaktadır. Bu araştırmada katılımcı görüşlerine göre elde edilen tüm veriler neticesinde; konut bahçelerindeki içilebilir bitki kullanımı ile ilgili bir bakış açısı ortaya konarak içilebilir peyzaj tasarımı kavramının önemi algılanmış ve daha sonraki çalışmalarda içilebilir peyzaj tasarım uygulamalarının teşvik edilmesi gerektiği sonucuna ulaşılmıştır.

\section{KAYNAKLAR}

Arslan, M., Kalaylıoğlu, Z., Ekren, E. (2018). Use of Medicinal and Aromatic Plants in Therapeutic Gardens. Article in Indian Journal of Pharmaceutical Education and Research 51(4S): 151-154.

Aslantürk, Ö.S. (2010). Aydın Yöresinde Kullanılan Bazı Tıbbi Bitkilerin Antioksidant ve Sitotoksik Etkilerinin Araştırılması. Doktora Tezi. Adnan Menderes Üniversitesi, Fen Bilimleri Enstitüsü, Aydın, Türkiye.

Atilabey, M., Yüksel, B., Uzunoğlu, F., Parlak, T., Oral, E. (2015). Orta Anadolu Kalkınma Ajansı. Tıbbi ve Aromatik Bitkiler Sektör Raporu, 16-30.

Bayram, E., Kırıcı, S., Tansı, S., Yılmaz, G., Arabacı, O., Kızıl, S., Telci, İ. (2010). Tıbbi ve Aromatik Bitkiler Üretiminin Arttırılması Olanakları. Türkiye Ziraat Mühendisliği VII. Teknik Kongresi Bildiriler Kitabı, Ankara, 437-456.

Bulut, G. (2005). Narman (Erzurum) ve Köylerinde Halk İlacı olarak Kullanılan Bitkiler. Yüksek Lisans Tezi. Atatürk Üniversitesi Sağlık Bilimleri Enstitüsü, Erzurum, Türkiye.

Burke, C. (2005). Contested Desires: The Edible Landscape of School. Paedagogica Historica 41(4-5): 571-587.

Çetin, M., Çobanoğlu, O. (2019). The Possibilities of Using Blue Spruce (Picea Pungens Engelm) As a Biomonitor By Measuring The Recent Accumulation of $\mathrm{Mn}$ in Its Leaves. Kastamonu University Journal of Engineering and Sciences 5(1): 43-50.
Dönmez, Ş., Çakır, M., Kef, Ş. (2016). Bartın'da Yetişen Bazı Tıbbi ve Aromatik Bitkilerin Peyzaj Mimarlığında Kullanımı. Süleyman Demirel Üniversitesi Mimarlık Bilimleri ve Uygulamaları Dergisi 1(2):1-8.

Erbaş, S. (2013). Türkiye'nin Bazı Tıbbi ve Aromatik Bitkileri, Doğa Koruma ve Milli Parklar Genel Müdürlüğü e-kitap, 158, Ankara, Türkiye.

Faydaoğlu, E., Sürücüoğlu, M. (2011). Geçmişten Günümüze Tıbbi ve Aromatik Bitkilerin Kullanılması ve Ekonomik Önemi. Kastamonu Üniversitesi Orman Fakültesi Dergisi 11(1): 52-67.

Göktaş, Ö., Gıdık, B. (2019). Tıbbi ve Aromatik Bitkilerin Kullanım Alanları. Bayburt Üniversitesi Fen Bilimleri Dergisi 2(1): 136-142.

Grimm, N., Grove, J.M., Pickett, S.T.A., Redman, C.L. (2000). Integrated Approaches to Long-Term Studies of Urban Ecological Systems. Bioscience 50: 571-584.

Gül, A., Küçük, V. (2001). Kentsel Açık-Yeşil Alanlar ve Isparta Kenti Örneğinde İrdelenmesi. Süleyman Demirel Üniversitesi Orman Fakültesi Dergisi A (2): 27-48.

Gül, V., Seçkin Dinler, B. (2016). Kumru (Ordu) Yöresinde Doğal Olarak Yetişen Bazı Tıbbi ve Aromatik Bitkiler. Süleyman Demirel Üniversitesi Ziraat Fakültesi Dergisi 11(1):146-156.

Jim, C.Y., Chen, W.Y. (2010). Habitat Effect on Vegetation Ecology and Occurrence on Urban Masonry Walls. Urban Forestry \& Urban Greening 9: 169-178.

Karataş, İ., Karataş, R., Elmastaş, M. (2019). Yaygın Olarak Kullanılan Bazı Tıbbi ve Aromatik Bitkilerin Sıcak Su İnfüzyonlarının Sekonder Metabolit İçeriği ve Antioksidan Aktivitelerinin Belirlenmesi. Gaziosmanpaşa Bilimsel Araştırma Dergisi 8(2): 49-57.

Kevseroğlu, K., Uzun, A., Çalışkan, V. (2014). Orta ve Doğu Karadeniz Bölgesi Doğal Florasında Belirlenen Tıbbi ve Aromatik Bitkiler. II. Tibbi ve Aromatik Bitkiler Sempozyumu Bildiriler Kitabı, Yalova, Türkiye, 108- 117.

Kırıcı, S. (2015). Türkiye'de Tıbbi ve Aromatik Bitkilerin Genel Durumu. TÜRKTOB, Türkiye Tohumcular Birliği Dergisi 4(15): 4-6.

Koçyiğit, M. (2005). Yalova İlinde Etnobotanik Bir Araştırma. Yüksek Lisans Tezi. İstanbul Üniversitesi, Sağlık Bilimleri Enstitüsü, İstanbul, Türkiye. Kökdil, G. (2002). Tıbbi Çaylar. Galenova 2: 19-21.

Kösa, S., Güral, S.M. (2019). Tıbbi ve Aromatik Bitkiler ve Peyzajda Kullanımları. Peyzaj - Eğitim, Bilim, Kültür ve Sanat Dergisi 1: 41- 54.

Kurt, P., Karaoğul, E. (2018). Bartın'da Aktarlarda Satılan Tıbbi Aromatik Bitkiler ve Ülkemizdeki Pazar Payları. Bartın Orman Fakültesi Dergisi 20(1): 73-80.

Olgun, R., Yılmaz, T., Türk, S. (2018). Parkların Bitkisel Tasarımında Yenilebilir Türlerin Kullanımı Üzerine Kullanıcı Görüşlerinin Antalya-Konyaaltı Örneğinde Araştırılması. Türkiye Peyzaj Araştırmaları Dergisi 1(1): 42-48.

Pouya, S., Demir, S. (2017). Peyzaj Mimarlığında Tıbbi ve Aromatik Bitkilerin Kullanımı. Uluslararası Sosyal Araştırmalar Dergisi 10(54): 1114-1125.

Sarı, A.O., Oğuz, B., Bilgiç, A., Tort, N., Gülseven, A. ve Şenol, S.G. (2010). Ege ve Güney Marmara Bölgelerinde Halk İlacı Olarak Kullanılan Bitkiler. Anadolu, J. of AARI, 20(2): $1-21$.

Selvi, S., Dağdelen, A., Kara, S. (2013). Kazdağlarından (Balikesir-Edremit) Toplanan ve Çay Olarak Tüketilen Tıbbi ve 
Aromatik Bitkiler. Tekirdag Ziraat Fakültesi Dergisi 10(2): 26-33.

Sevik, H., Ozel, H.B., Cetin, M., Ozel, H.U., Erdem, T. (2019). Determination of Changes in Heavy Metal Accumulation Depending on Plant Species, Plant organism and Traffic Density in Some Landscape Plants. Air Quality, Atmosphere and Health 12(2): 189-195.

Sevik, H., Cetin, M., Ozel, H.B., Ozel, S., Zeren Cetin, I. (2020). Changes in Heavy Metal Accumulation in Some Edible Landscape Plants Depending on Traffic Density. Environmental Monitoring Assessment 192: 78.

Sıcak, Y., Çolak, Ö.F., İlhan, V., Sevindik, E., Alkan, N. (2013). Köyceğiz Yöresinde Halk Arasında Yaygın Olarak KullanıIan Bazı Tıbbi ve Aromatik Bitkiler. Anadolu Doğa Bilimleri Dergisi 4(2): 70-77.

TÜIK, (2019). Türkiye İstatistik Kurumu (TUIK) Nüfus ve Vatandaşlık İşleri Genel Müdürlüğü, Adrese Dayalı Nüfus Sistem Kayıt Sonuçları, 2019. http://www.tuik.gov.tr/PreHaberBultenleri.do?id=33705. (Erişim tarihi:01.09.2020)

Turkyilmaz, A., Cetin, M., Sevik, H., Isinkaralar, K., Saleh, E.A.A. (2018). Variation of Heavy Metal Accumulation in Certain Landscaping Plants Due to Traffic Density. Environment, Development and Sustainability 1-14.

United Nations, (2019). Department of Economic and Social Affairs, Population Division, World Urbanization Prospects
2018: Highlights (ST/ESA/SER.A/421). https://population.un.org/wup/ Publications/Files/WUP2018-Highlights.pdf. (Erişim Tarihi:03.12.2020)

URL-1, (2020). İzmir İ Kültür ve Turizm müdürlüğü, Genel Bilgiler. https://izmir.ktb.gov.tr/TR-77342/genel-bilgiler.html. (Erişim Tarihi:01.09.2020)

URL-2, (2020). Harita Genel Müdürlüğü, İl ve İlçe Yüz Ölçümleri. https://www.harita.gov.tr/images/urun/il_ilce_alanlari.pdf. (Erişim Tarihi:01.09.2020)

URL-3, (2020). İzmir İlçeleri. https://www.izmirde.biz/?pnum=642\&st=\%C4\%B0ZM\%C4\%B0R\%20 \%C4\%BOL\%C3\%87ELER\%C4\%B0. (Erişim Tarihi:03.12.2020)

Yalçınalp, E., Demirci, Ö. (2018). Kent Parklarında Yenilebilir Bitki Talebine Etki Eden Kullanıcı Özellikleri. Türk Tarım ve Doğa Bilimleri Dergisi 5(4): 666-675.

Yücel, G., Evren, D. (2010). Tıbbi-Aromatik Bitkilerin Bahçe Tasarımlarında ve Kaya Bahçelerinde Dış Mekân Süs Bitkisi Olarak Kullanım Olanakları. IV. Süs Bitkileri Kongresi Bildiri Kitabı, Erdemli-Mersin, Türkiye, 529-534.

Yücer, A., Altıntaş, G. (2012). Türkiye'nin Tıbbi ve Aromatik Bitkiler Politikaları. I. Tıbbi ve Aromatik Bitkiler Sempozyumu Bildiri Kitabı, Tokat, Türkiye, 290-297. 